\title{
Photochemical transformation of terrestrial dissolved organic matter supports hetero- and autotrophic production in coastal waters
}

\author{
Anssi V. Vähätalo ${ }^{1,2, *}$, Hanna Aarnos ${ }^{1,3}$, Laura Hoikkala ${ }^{1,4}$, Risto Lignell ${ }^{1,4}$ \\ ${ }^{1}$ Tvärminne Zoological Station, University of Helsinki, Hanko, Finland \\ ${ }^{2}$ Present address: ARONIA Coastal Zone Research Team, Åbo Akademi University \& Novia University of Applied Sciences, \\ Ekenäs, Finland \\ ${ }^{3}$ Present address: Department of Environmental Sciences, University of Helsinki, Helsinki, Finland \\ ${ }^{4}$ Present address: Marine Center, Finnish Environmental Institute, Helsinki, Finland
}

ABSTRACT: We assessed the responses of a nitrogen (N)-limited $<10 \mu \mathrm{m}$ plankton community from the Baltic Sea to the 12 d photochemical transformation of dissolved organic matter (DOM). The photochemical transformation of DOM increased the biomass and the production of heterotrophic bacteria, flagellates, and ciliates in the following $10 \mathrm{~d}$ bioassay. The succession of heterotrophic plankton indicated a 3-level trophic transfer of photoproduced bioavailable DOM through bacteria and flagellates to ciliates. The photochemical transformation of DOM also stimulated the biomass and the production of phytoplankton through the photoproduction of bioavailable $\mathrm{N}$ initially incorporated into bacterial biomass. The grazing of bacterioplankton supplied $\mathrm{N}$ to phytoplankton directly, presumably due to mixotrophy, and indirectly by releasing dissolved N. The carbon stable isotope signature of plankton biomass was similar to that of allochthonous carbon, indicating that the photochemical transformations concerned primarily terrestrial DOM and therefore represented a microbial link between terrestrial DOM and planktonic production. The bacterial production stimulated by the photochemically produced labile DOM was related to the number of photons absorbed during the photochemical transformation of DOM for the determination of apparent quantum yield. According to the apparent quantum yield, the calculated summertime photoproduction of labile substrates contributes 2 to $5 \%$ to total bacterial production in the northern Baltic Sea. According to this study, the photochemical transformation of terrestrial DOM influences not only the initial production of bacterioplankton but can also stimulate higher trophic levels and autotrophic plankton in coastal waters.

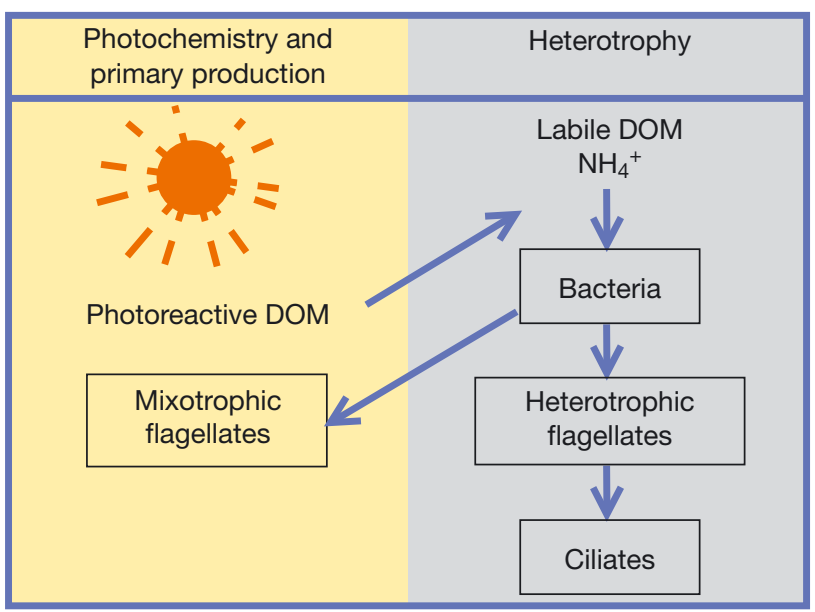

Solar radiation induces the flux of photoreactive DOM through a heterotrophic food chain with a linkage to autotrophic plankton (mixotrophic flagellates).

Image: A. Vähätalo

KEY WORDS: Dissolved organic nitrogen - Apparent quantum yield - Trophic transfer • Photochemistry • Bacterioplankton • Phytoplankton Resale or republication not permitted without
written consent of the publisher

\section{INTRODUCTION}

Biologically recalcitrant dissolved organic matter (DOM) is the largest pool of organic carbon and a major potential source of nutrients in the water column of most aquatic ecosystems (Wetzel et al. 1995, Hansell 
\& Carlson 2002). Solar radiation-induced photochemical reactions transform biologically recalcitrant DOM into inorganic species $\left(\mathrm{CO}_{2}, \mathrm{NH}_{4}^{+}\right)$and labile DOM supporting bacterial metabolism (Moran \& Zepp 1997, Mopper \& Kieber 2002, Vähätalo 2009). Here we use the term 'photoproduced DOM' when we refer to the photochemical transformation of biologically recalcitrant DOM into bioavailable forms.

Although numerous studies have shown that the photochemical transformation of biologically recalcitrant DOM stimulates bacterial production (reviewed by Mopper \& Kieber 2002, Vähätalo 2009), we know little about the trophic transfer of photoproduced DOM to upper trophic levels and thus to the whole secondary production of aquatic ecosystems (De Lange et al. 2003, Daniel et al. 2006). De Lange et al. (2003) showed that photoproduced DOM stimulates hetero- and mixotrophic nanoplankton in Lake Lacawac (eastern Pennsylvania, USA), which receives DOC from an adjacent bog. The irradiation of this bog water also stimulated the egg production of Daphnia, but a similar irradiation of water from the nearby low-DOC Lake Giles did not cause any trophic transfer of photoproduced DOM (De Lange et al. 2003). Artificial UV-irradiation increased the biomasses of flagellates, ciliates, cladocerans, and copepods in a following $7 \mathrm{wk}$ long dark bioassay in water from humic Lake Skärshult, but not in water from eutrophic Lake Vomb (both lakes in southern Sweden; Daniel et al. 2006). Thus, according to the limited information available, the trophic transfer of photoproduced DOM is confined to humic waters.

In order to assess the importance of photoproduced DOM to aquatic ecosystems, we need to predict the magnitude of bacterial production stimulated by the phototransformation of DOM. Miller et al. (2002) reported apparent quantum yields for bacterial respiration stimulated by phototransformed DOM. Bacteria can respire the photoproduced DOC to $\mathrm{CO}_{2}$, but from the trophic transfer point of view it is more appropriate to evaluate the production of bacterial biomass based on photoproduced DOM. To our knowledge, apparent quantum yields for bacterial production have not been reported.

Although photochemistry is able to incorporate bioavailable nitrogen $(\mathrm{N})$ into recalcitrant forms (Kieber et al. 1997), the photoproduction of ammonium $\left(\mathrm{NH}_{4}{ }^{+}\right)$ and amino acids from recalcitrant dissolved organic nitrogen (DON) can potentially stimulate primary producers under conditions where bioavailable $\mathrm{N}$ limits primary production (Bushaw et al. 1996, Vähätalo \& Järvinen 2007). Such N-limiting conditions are common in both fresh and marine waters (Rabalais 2002, Bergström \& Jansson 2006). Even though photoproduced $\mathrm{N}$ can serve as a nutrient for autotrophic plankton and potentially stimulate primary production, this has been examined and observed only in 1 study (Vähätalo \& Järvinen 2007). Vähätalo \& Järvinen (2007) demonstrated the stimulus of primary producers as elevated concentrations of chlorophyll $a$ (chl a) and a single microscopic examination of plankton community.

The objective of our study was to assess how the Nlimited hetero- and autotrophic plankton of the Baltic Sea respond to photoproduced N and labile DOM. Our experiment consisted of 3 phases: (1) a pre-treatment for the consumption of bioavailable $\mathrm{N}_{i}(2)$ an exposure of biologically recalcitrant DOM to solar radiation to generate photoproduced DOM and $\mathrm{N}_{i}$ and (3) a bioassay for the responses of hetero- and autotrophic plankton to the photoproduced DOM and N. We describe the dynamic responses of the plankton community to the phototransformation of DOM in a detailed time series including the production and biomass of bacterioplankton, its grazers, as well as taxa-specific responses of the phytoplankton community. To put the experimental results in an environmental perspective, the photoproduced $\mathrm{N}$ and the bacterial production based on photoproduced DOM were related to the absorbed dose of solar radiation. This relation was used to calculate the apparent quantum yields for the photoproduction of bioavailable $\mathrm{N}$ and the bacterial production based on photoproduced DOM.

\section{MATERIALS AND METHODS}

Sampling. This study was carried out in the coastal northern Baltic Sea at the entrance to the Gulf of Finland. In the study region, the typical seasonal succession of plankton includes a vernal bloom dominated by diatoms and dinoflagellates (April to mid-May), followed by a N-deplete period with pico- and nanophytoplankton in mid-May to mid-July, and diazotrophic filamentous cyanobacteria in mid-July to August (Lignell et al. 2003). The water sample (30 l over 0 to $5 \mathrm{~m}$ depth at $5.5^{\circ} \mathrm{C}$ temperature) was collected from the $42 \mathrm{~m}$ deep Stn Långskär $\left(59^{\circ} 47^{\prime} \mathrm{N}, 23^{\circ} 19^{\prime} \mathrm{E}\right.$, surface salinity 5.5) into acid-rinsed polyethylene containers with a Limnos sampler on 19 May 2005. After sampling, only acid-rinsed containers were used, and quartz- and glassware were additionally combusted at $450^{\circ} \mathrm{C}$ for $2 \mathrm{~h}$ prior to use.

Experimental design. A pre-treatment was designed to reduce the concentration of bioavailable dissolved $\mathrm{N}$ for easy detection of the photochemical production of bioavailable $\mathrm{N}$ from biologically recalcitrant DON after the sunlight exposure phase of the experiment. For the pre-treatment, the $0.2 \mu \mathrm{m}$ filtrate (Sartobran 300, Sartorius) was inoculated with a $10 \mu \mathrm{m}$ reverse-phase filtrate ( $22 \%$ of final volume) of the 
original water sample. To ensure N-limiting conditions, we introduced $\mathrm{KH}_{2} \mathrm{PO}_{4}$ (pro analysi, Merck) to the final concentration of $1.5 \mu_{\mathrm{mol} \mathrm{l}} \mathrm{l}^{-1}$. The concentration of phosphate $\left(\mathrm{PO}_{4}{ }^{3-}\right)$ did not decrease below $1.1 \mathrm{mmol} \mathrm{l}^{-1}$ at any phase of the experiment (results not shown), indicating that the introduction was sufficiently high but still realistic, since the concentration of $\mathrm{PO}_{4}{ }^{3-}$ frequently exceeds $1.5 \mu \mathrm{mol} \mathrm{l^{-1 }}$ prior to a vernal bloom in our study region (Spilling 2007). The pre-treatment culture was incubated for $6 \mathrm{~d}$ at $10^{\circ} \mathrm{C}$ in a transparent polycarbonate carboy under photosynthetically active radiation (PAR; Philips, Natural daylight $35 \mathrm{~W}$ model 965) following an 18:6 h light:dark cycle with the scalar photon flux densities of $100 \mu \mathrm{mol}$ PAR $\mathrm{m}^{-2} \mathrm{~s}^{-1}$ measured with a QSL2101 light meter (Biospherical Instruments). The irradiance of PAR lamps at wavelengths $<430 \mathrm{~nm}$ and the photochemical transformation of DOM under the PAR lamps was negligible (Vähätalo \& Järvinen 2007).

After pre-treatment, the water was aseptically filtered $(0.2 \mu \mathrm{m}$, Sartobran 300, Sartorius) into 36 quartz (diameter $51 \mathrm{~mm}$, mean volume $221 \mathrm{ml}$ ) and 7 glass bottles (volume $1177 \mathrm{ml}$ each) in a laminar flow hood. For the exposure to solar radiation, the quartz bottles were laid into a $121 \mathrm{~mm}$ deep matte black outdoor pool flushed with tap water, along with the glass bottles covered with aluminum foil (dark controls). The constant inflow of tap water kept the pool water temperature between $11.8^{\circ} \mathrm{C}$ and $15.3^{\circ} \mathrm{C}$ over the $12 \mathrm{~d}$ exposure, mimicking the diurnal fluctuation in surface water temperature at the sampling site to within a few degrees.

For the bioassay, the dark and the exposed waters were pooled by treatment into 2 transparent polycarbonate containers and inoculated with an indigenous plankton community from 0 to $5 \mathrm{~m}$ depth of Stn Långskär $(10 \mu \mathrm{m}$ reverse-phase filtrate into $10 \%$ of final volume, collected on 7 June 2005). The waters were incubated under PAR and without ultraviolet radiation (UVR) for $12 \mathrm{~d}$ as described for the pre-treatment. During the experiment, the water was periodically sampled by pouring aliquots for chemical analyses and for the assessment of the composition and the activities of plankton.

Analytical determinations. Dissolved organic carbon (DOC) and total dissolved nitrogen (TDN) were determined in triplicates. Water samples $(20 \mathrm{ml})$ were filtered (0.2 $\mu \mathrm{m}$ syringe filter; Minisart, Sartorius) and acidified ( $80 \mu \mathrm{l}$ of $2 \mathrm{~mol} \mathrm{l}^{-1}$ hydrochloric acid into the filtrate). The inorganic carbon was purged following the catalytic combustion $\left(670^{\circ} \mathrm{C}\right)$ of organic carbon and nitrogen into $\mathrm{CO}_{2}$ and nitrogen oxides, which were measured by infrared and chemiluminometric detection, respectively, with a total organic carbon and total nitrogen analyzer (TOC- $\mathrm{V}_{\mathrm{CPH}}$, Shimadzu).
For the analysis of dissolved nutrients, triplicate water samples were filtered through $0.2 \mu \mathrm{m}$ (Minisart, Sartorius) and frozen $\left(-20^{\circ} \mathrm{C}\right) . \mathrm{NH}_{4}{ }^{+}$was determined by a phenolhypochlorite method (detection limit $0.25 \mu \mathrm{mol}$ $\mathrm{l}^{-1}$, Solorzano 1969). The combined concentrations of nitrate and nitrite $\left(\mathrm{NO}_{2}^{-}+\mathrm{NO}_{3}^{-}\right)$were determined with Lachat QuikChem Method 31-107-04-1-A (detection limit $0.1 \mu \mathrm{mol} \mathrm{l}^{-1}$ ). $\mathrm{PO}_{4}{ }^{3-}$ was determined with Lachat QuikChem Method 31-115-04-3-A. For the total dissolved $\mathrm{P}$ (TDP), the water sample was digested with persulfate in boric acid-NaOH buffer, and the formed $\mathrm{PO}_{4}{ }^{3-}$ was analyzed as described above (Hansen \& Koroleff 1999). The concentration of DON and dissolved organic phosphorus (DOP) were calculated as TDN $\left(\mathrm{NO}_{2}{ }^{-}+\mathrm{NO}_{3}{ }^{-}\right)-\mathrm{NH}_{4}{ }^{+}$and TDP $-\mathrm{PO}_{4}{ }^{3-}$, respectively.

For the determination of particulate nutrients, carbon, and the stable isotope composition $\left(\delta^{13} \mathrm{C}\right)$, the particulate matter from triplicate $100 \mathrm{ml}$ water samples was filtered on combusted, acid-rinsed glass fiber filters (GF/F, $25 \mathrm{~mm}$, Whatman, $0.7 \mu \mathrm{m}$ ) with an acid-rinsed filtration unit made from glass. For particulate organic $\mathrm{N}$ (PON) and $\mathrm{P}(\mathrm{POP})$, the particulate matter on the filters was digested and determined as $\mathrm{NO}_{2}{ }^{-}+\mathrm{NO}_{3}{ }^{-}$and $\mathrm{PO}_{4}{ }^{3-}$, respectively, as described above for dissolved nutrients. For the $\delta^{13} \mathrm{C}$ and the concentration of particulate organic carbon (POC), the particulate matter on filters along a glycine standard with known $\delta^{13} \mathrm{C}$ was determined with an isotope ratio mass spectrometer (Europa Scientific Automated Nitrogen Carbon Analysis-MS 20-20). Isotope values are reported relative to Vienna Pee Dee Belemnite, and expressed in standard delta $\left(\delta^{13} \mathrm{C}\right)$ notation as parts per thousand $(\%)$.

Particulate matter from duplicate $100 \mathrm{ml}$ water samples was GF/F filtered (25 mm, Whatman), for the extraction of $\mathrm{Chl} a$ with ethanol. Chl a was determined as an emission at $670 \mathrm{~nm}$ induced by a $450 \mathrm{~nm}$ excitation with a spectrofluorometer (Shimadzu RF-5000; detection limit $0.02 \mu \mathrm{g} \mathrm{l}^{-1}$ ).

The absorption by chromophoric DOM (CDOM) was determined from $0.2 \mu \mathrm{m}$ filtered (Minisart, Sartorius) waters against a Milli-Q-water blank in a $10 \mathrm{~cm}$ quartz cuvette with a scanning spectrophotometer (Shimadzu UV-2101PC). The absorbance spectrum was scanned 3 times with a new blank each time at $1 \mathrm{~nm}$ intervals and converted into an absorption coefficient $\left(a_{\mathrm{CDOM}, \lambda}\right)$. The spectral slope coefficient of $a_{\mathrm{CDOM}, \lambda}$ was calculated by the log-linear fitting method from 300 to $550 \mathrm{~nm}$, because this range of the spectrum interacts with photolytic solar radiation and has an $a_{\mathrm{CDOM}, \lambda}$ more than 3 -fold above the detection limit of the method.

Microscopy. For the determination of bacterial biomass, the samples were preserved with glutaraldehyde (final concentration of $5 \%$ ), filtered on Poretics polycarbonate $0.22 \mu \mathrm{m}$ filters and stained with acridine orange. For the biovolumes of bacteria, $\geq 200$ 
bacterial cells from $\geq 20$ fields were counted with an epifluorescence microscope, and the cell volumes were determined by digital image analysis (Massana et al. 1997). The biovolumes were converted to bacterial carbon biomasses using a conversion factor of $0.12 \mathrm{pg} C\left(\mu \mathrm{m}^{3}\right)^{0.7}$. The detection limit of the method

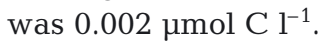

The samples were stained with proflavine for the determination of the most abundant small-sized taxa: heterotrophic nanoflagellates $\left(14 \mu^{3}\right.$, mean volume in early summer, Kuuppo 1994; detection limit $0.05 \mu \mathrm{mol}$ $\left.\mathrm{C}^{-1}\right)$, Pseudopedinella $\left(50 \mu^{3}\right)$, picocyanobacteria $\left(0.38 \mu^{3}\right)$, Monoraphidium $\left(50 \mu^{3}\right)$, and Micromonas ( $2 \mathrm{\mu m}^{3}$; Olenina et al. 2006). The cells were identified and counted under blue excitation light assessing green emission for all cells and red emission for the autotrophs with chloroplasts. The green excitation and red emission setting was used for the determination of picocyanobacteria with phycoerythrine. The biomass of ciliates $\left(2000 \mathrm{\mu m}^{3}\right)$ and phytoplankton (all taxa) was determined with a settling chamber technique using the counted cell densities and the published cell volumes (Olenina et al. 2006). The carbon biomass was estimated from the biovolumes according to a $0.22 \mathrm{pg}$ $\mathrm{C} \mu \mathrm{m}^{-3}$ conversion (Børsheim \& Bratbak 1987). To estimate the coefficient of variation (CV) among the biomass determinations for each microscopic method, we counted 3 replicate samples, which had CV 25\% for the settling chamber technique, CV $28 \%$ for the epifluorescence microscopy of algae-flagellates, and CV $6 \%$ for heterotrophic bacteria.

Primary production. Primary production was measured by the ${ }^{14} \mathrm{C}$ method as in an earlier study (Lignell et al. 2003). Samples from the bioassay and $\mathrm{NaH}^{14} \mathrm{CO}_{3}$ were introduced to $20 \mathrm{ml}$ glass scintillation vials. Duplicate light vials were irradiated along with dark vials for $3 \mathrm{~h}$ under $104 \mu \mathrm{mol}$ PAR m $\mathrm{m}^{-2} \mathrm{~s}^{-1}$ at $10^{\circ} \mathrm{C}$. Total ${ }^{14} \mathrm{CO}_{2}$ fixation (particulate plus dissolved organic ${ }^{14} \mathrm{C}$ ) was measured after the removal of inorganic $\mathrm{C}$ from the acidified samples. The ${ }^{14} \mathrm{C}$ activity was measured using scintillation cocktail (HiSafe III, Wallac) with a liquid scintillation counter (Wallac Win 1414). Primary production ( $\mu \mathrm{mol} \mathrm{C}^{-1} \mathrm{~h}^{-1}$ ) was calculated from the dark-corrected fixation of ${ }^{14} \mathrm{C}$ accounting for the measured concentration of dissolved inorganic carbon. The daily photosynthesis was estimated by multiplying the measured primary production with the 18 irradiated $h$ $\mathrm{d}^{-1}$ of the bioassay.

Bacterial production. Bacterial production was determined by a ${ }^{3} \mathrm{H}$-thymidine method (Hoikkala et al. 2009). Each determination included triplicate samples and 2 formaldehyde-treated blanks per treatment. The radioactivity of ${ }^{3} \mathrm{H}$-thymidine was measured with a Wallac Win spectral 1414 liquid scintillation counter. Net bacterial production was estimated from the thymidine incorporation, the measured bacterial cell carbon content and a ${ }^{3} \mathrm{H}$-thymidine conversion factor of $1.1 \times 10^{18}$ cells mol $^{-1}$.

Optical model for bacterial production supported by photoproduced DOM. The bacterial production supported by photoproduced DOM in an optically thin water layer at depth $z\left(\mathrm{pbp}_{z}\right.$, mol $\left.\mathrm{C} \mathrm{m}^{-3} \mathrm{~d}^{-1}\right)$ can be expressed as

$$
\operatorname{pbp}_{z}=\int_{\lambda \min }^{\lambda \max } \phi_{\mathrm{bp}, \lambda} Q_{\mathrm{s}, z, \lambda} a_{\mathrm{CDOM}, \lambda} \mathrm{d} \lambda
$$

where $\phi_{\mathrm{bp}, \lambda}$ is the apparent quantum yield for bacterial production supported by photoproduced DOM at wavelength $\lambda$ (mol bacterial $\mathrm{C} \mathrm{mol}^{-1}$ absorbed photons $\left.\mathrm{nm}^{-1}\right), Q_{\mathrm{s}_{z}, \lambda}$ is the scalar photon flux density at $\lambda$ and depth $z$ (mol photons $\mathrm{m}^{-2} \mathrm{~d}^{-1} \mathrm{~nm}^{-1}$ ), and $a_{\mathrm{CDOM}, \lambda}$ is the absorption coefficient of CDOM at $\lambda\left(\mathrm{m}^{-1} \mathrm{~nm}^{-1}\right)$. The integration of Eq. (1) is over the wavelength range from $\lambda_{\min }$ to $\lambda_{\text {max }}$, the minimum and maximum wavelengths $(\mathrm{nm})$, respectively, contributing to the bacterial production supported by photoproduced DOM.

Over the entire water column, the bacterial production supported by photoproduced DOM (pbp, mol C $\left.\mathrm{m}^{-2} \mathrm{~d}^{-1}\right)$ is

$$
\operatorname{pbp}=\int_{\lambda \min }^{\lambda \max } \phi_{\mathrm{bp}, \lambda} Q_{\mathrm{a}, \lambda} a_{\mathrm{CDOM}, \lambda} / a_{\mathrm{tot}, \lambda} \mathrm{d} \lambda
$$

where $Q_{\mathrm{a}, \lambda}$ represents mol of photons absorbed by the water column (mol photons $\mathrm{m}^{-2} \mathrm{~d}^{-1} \mathrm{~nm}^{-1}$ ), and the $a_{\mathrm{CDOM}, \lambda} / a_{\text {tot }, \lambda}$ ratio is the fractional contribution of CDOM to the total absorption coefficient, $a_{\text {tot }, \lambda}$.

The apparent quantum yield for bacterial production supported by photoproduced DOM was assumed to increase exponentially with decreasing wavelength as has been found for many photochemical reactions with natural DOM (Vähätalo 2009),

$$
\phi_{\mathrm{N}, \lambda}=c \mathrm{e}^{-d \lambda}
$$

where $C$ (mol C mol ${ }^{-1}$ photons) and $d\left(\mathrm{~nm}^{-1}\right)$ are positive parameters and $\lambda$ is wavelength (in $\mathrm{nm}$ ). The photoproduction of bioavailable $\mathrm{N}$ at depth $z\left(p \mathrm{~N}_{z}\right)$ and over the entire water column $(p N)$ was calculated according to the modified Eqs. (1) and (2), respectively, using an apparent quantum yield for the photoproduction of bioavailable $\mathrm{N}\left(\phi_{\mathrm{N}, \lambda}, \mathrm{mol} \mathrm{N} \mathrm{mol}^{-1}\right.$ photons $\left.\mathrm{nm}^{-1}\right)$ instead of $\phi_{\mathrm{bp}, \lambda}$ (Vähätalo \& Järvinen 2007).

Determination of apparent quantum yields. The number of photons absorbed by CDOM during the exposure to solar radiation (the product of $Q_{\mathrm{S}, z, \lambda}$ and $a_{\mathrm{CDOM}, \lambda}$ of Eq. 1) was estimated by a radiative transfer model (details in Vähätalo \& Järvinen 2007), which used the information about the solar radiation measurements as well as the optical characteristics of the cooling water and the water samples. The solar radiation incident to the pool was measured every $12 \mathrm{~s}$ with 
a Vantage Pro 6450 global radiation sensor, and the mean of 50 measurements was logged every $600 \mathrm{~s}$. The radiative transfer model separated solar radiation into direct and indirect parts according to the turbidity and the Rayleigh scatter. The specular reflection from the interface between the atmosphere and the cooling water in the pool was calculated according to Fresnel's law of reflection. The attenuation of solar radiation due to the cooling water was calculated according to the vertical attenuation coefficient of downward photon flux in that medium. The number of photons absorbed by the CDOM of exposed water was calculated as the difference of photons entering the water sample and those passing the sample water after the mean depth of the sample $(39.7 \mathrm{~mm}$, the mean optical depth of the sample $=0.5 \pi r$, where $r=$ the inner radius of the bottle; Vähätalo \& Zepp 2005). The photochemical decomposition of CDOM during exposure was accounted for by calculating the mean $a_{\mathrm{CDOM}, \lambda}$ for the exposure period according to the first-order kinetic decay. The reflectance from the matte black lining of the pool was considered negligible. The calculations of photon fluxes were done at $1 \mathrm{~nm}$ bands through 300 to $700 \mathrm{~nm}$ at $10 \mathrm{~min}$ intervals, and summed over the time of exposure.

The apparent quantum yield spectrum for the photoreactions of DOM producing bioavailable $N\left(\phi_{N, \lambda}\right)$ was calculated from the measured difference in the concentrations of PON between the exposed and the dark control waters during the bioassay. This difference represents $p N_{z}$ of Eq. (1) when the equation is modified for modeling of N. Similarly, the photochemistry-derived stimulus to bacterial production $\left(\mathrm{pbp}_{z}\right.$ of Eq. 1) was used for the calculation of $\phi_{\mathrm{bp}, \lambda}$. The photoproduction of $\mathrm{N}$ or the stimulated production of bacterial carbon was related to the number of photons absorbed by CDOM at $1 \mathrm{~nm}$ bands in the spectral range of 300 to $700 \mathrm{~nm}$, which includes those wavelengths of solar radiation contributing to DOM photochemistry (Moran \& Zepp 1997). Each of the 401 spectral bands was assumed to contribute to the photoreactions with the spectral weighing described by Eq. (3), where weighing increases exponentially with decreasing wavelength in a manner specified by the parameters $c$ and $d$. The 401 bands of absorbed photons were related to the measured photoproduction of $\mathrm{N}$ or to the stimulus in the bacterial production by unconstrained nonlinear optimization (the fminsearch-function of Matlab6) so that the resulting $c$ and $d$ of Eq. (3) gave the best fit between the measured and calculated (Eq. 1) values.

The error in $\phi_{\mathrm{N}, \lambda}$ and $\phi_{\mathrm{bp}, \lambda}$ depended on the error in the parameters used for their determination (i.e. $p \mathrm{~N}_{z}$ or $\operatorname{pbp}_{z 1} Q_{\mathrm{s}_{1}, \lambda}$, and $a_{\mathrm{CDOM}, \lambda}$ of Eq. 1). The CV for the determination of $a_{\mathrm{CDOM}, \lambda}$ was ca. $0.3 \%$ at the UV-A
(315 to $400 \mathrm{~nm}$ ) part of the spectrum, which was primarily responsible for the photochemical reactions. We estimated that the error of the radiometer and that of the radiative transfer model resulted in $\mathrm{CV}<15 \%$ for the estimated irradiance at the UV-A range of the spectrum approximating $Q_{\mathrm{S}, z, \lambda}$ (discussed by Vähätalo et al. 2000). The error in $p \mathrm{~N}_{z}$ and $\mathrm{pbp}_{z}$ depended on the standard deviation associated with the determination of the photoproduced PON (CV ca. 15\%) and the bacterial production based on photoproduced DOM (CV $<10 \%$ ). When the CV of each component affecting the determination of $\phi_{\lambda}$ was summed, the $\mathrm{CV}$ estimate was ca. $30 \%$ for $\phi_{\mathrm{N}, \lambda}$ and ca. $25 \%$ for $\phi_{\mathrm{bp}, \lambda}$.

Statistical analyses. The experimental design of this study included an irradiated water sample and its dark control, and therefore we were not able to test differences between true replicates. However, we made our analytical determinations typically from duplicate or triplicate aliquots, which allowed us to test the statistical differences within the uncertainty of the aliquots ( $\mathrm{df}=4$ or 2 ). These statistical differences between the treatments within the uncertainty of aliquots were tested with a $t$-test using 2-tailed distributions and equal variances for replicated measurements at a single time point, while paired $t$-tests were applied for data including several time points.

Most biomass determinations by microscopy were not replicated but based on single aliquots. However, we estimated the $\mathrm{CV}$ for each method of microscopy from triplicate determinations. To assess whether the difference between treatments was larger than the deviation of the microscope method, we used the standard deviation of biomass estimates (based on the CV of separate determinations) and applied a $t$-test assuming 3 replicated determinations (i.e. $\mathrm{df}=4$ ) for each time point.

\section{RESULTS}

During the collection of the original water sample in late May from the Baltic Sea, the Secchi depth $(7 \mathrm{~m})$ and the concentration of chl a deviated from typical values during the vernal bloom (Table 1; bloom Secchi: $4 \mathrm{~m}$, bloom chl a: $40 \mathrm{mg} \mathrm{m}^{-3}$; Spilling 2007). The concentration of dissolved inorganic nitrogen (DIN) was negligible and less than typical (i.e. ca. $7 \mu \mathrm{mol}$ DIN $~^{-1}$ ) prior to the vernal bloom in our study region (Table 1, Spilling 2007). The ratio of DIN to phosphate-phosphorus (DIN:PO ${ }_{4}{ }^{3-}$ ) was 2.4 and less than 16 , the optimum for algal growth (the Redfield ratio). Thus, several cues indicate that phytoplankton was N-limited during the collection of the sample as is typical for our study region during late spring or early summer. 
Table 1. Concentration of ammonium, phosphate, nitrite + nitrate, dissolved and particulate carbon (DOC and POC, respectively), organic nitrogen (DON and PON), and organic phosphorus (DOP and POP; $\mu \mathrm{mol} \mathrm{l}^{-1}$; mean $\pm \mathrm{SD} \mathrm{n}=2$ to 5 ) and chlorophyll $a\left(\mathrm{chl} a_{;} \mu \mathrm{g} \mathrm{l}^{-1}\right.$ ) as well as the $\delta^{13} \mathrm{C}$ of POC (\%) in the water collected on 19 May 2005 from Stn Långskär

\begin{tabular}{|lc|}
\hline Parameter & Measured value \\
\hline $\mathrm{DOC}$ & $449 \pm 39$ \\
$\mathrm{DON}$ & $20.4 \pm 1.2$ \\
$\mathrm{NH}_{4}{ }^{-}$ & $0.17 \pm 0.16$ \\
$\mathrm{NO}_{2}{ }^{-}+\mathrm{NO}_{3}{ }^{-}$ & $0.05 \pm 0.03$ \\
$\mathrm{DOP}$ & $0.22 \pm 0.04$ \\
$\mathrm{PO}_{4}{ }^{3-}$ & $0.09 \pm 0.01$ \\
$\mathrm{POC}_{\mathrm{PON}}$ & $71.6 \pm 7.4$ \\
$\mathrm{POP}$ & $4.46 \pm 0.15$ \\
$\mathrm{Chl} a$ & $0.33 \pm 0.02$ \\
$\delta^{13} \mathrm{C}$ & $5.3 \pm 0.1$ \\
\end{tabular}

\section{Pre-treatment for the removal of bioavailable $\mathbf{N}$}

To reduce bioavailable $\mathrm{N}$ (mainly DON) further, the pre-treatment included filtering the original water sampled and the introductions of plankton inoculum as well as $\mathrm{PO}_{4}{ }^{3-}$, which reduced the DIN:PO ${ }_{4}{ }^{3-}$ to 0.15 . The initially low concentration of DIN remained close or below the detection limits during the pre-treatment and also at the later phases of the experiments (data not shown). During the pre-treatment, the concentrations of POC, PON, and POP increased (Fig. 1A-C). The biomass of phytoplankton determined by microscopy increased, although this was not seen as an elevated concentration of chl a (Fig. 2). The biomass of bacteria, heterotrophic nanoflagellates, and ciliates increased (Fig. 3). The increase of PON by $0.38 \mu \mathrm{mol} \mathrm{N}$ $\mathrm{l}^{-1}$ likely occurred at the expense of DON, because the measured concentration of inorganic $\mathrm{N}$ was negligible, and $\mathrm{N}$-fixing cyanobacteria were not detected by microscopy at any part of the experiment. When the PON (0.38 $\mu \mathrm{mol} \mathrm{N}^{-1}$ ) accumulated during the pretreatment was compared to the initial concentration of DON, we found that $1.9 \%$ of DON was readily bioavailable for plankton and that the majority of DON was not directly bioavailable.

\section{Exposure of DOM to solar radiation}

After the incorporation of bioavailable $\mathrm{N}$ into particulate organic matter (POM) during the pre-treatment, the residual DOM was separated by filtering $(0.2 \mu \mathrm{m})$ and exposed to natural solar radiation or enclosed in aluminum foil covered bottles, which served as the dark controls. The absorption coefficient of CDOM
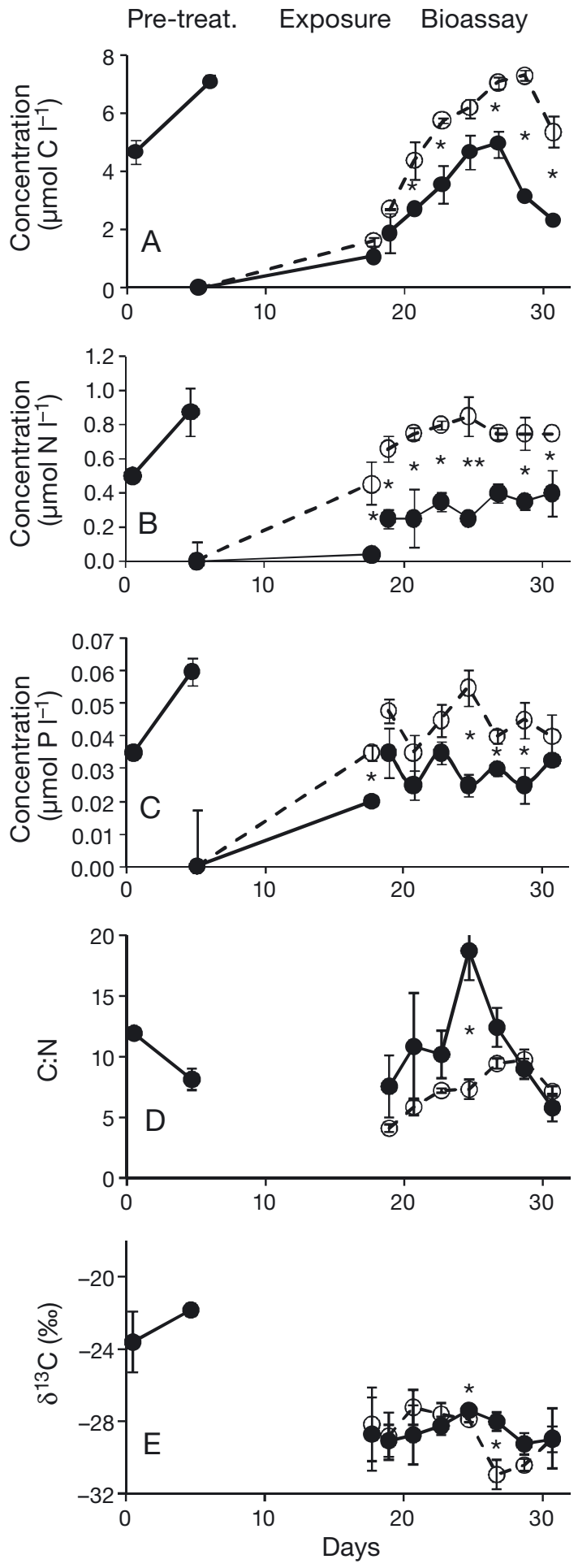

Fig. 1. Concentration of particulate organic (A) carbon, (B) nitrogen, and (C) phosphorus, as well as the (D) C:N ratio and (E) $\delta^{13} \mathrm{C}$ of particulate matter during the 3 phases of the experiment (pre-treatment, exposure, and bioassay) in the solar radiation-exposed (open circles) and the dark control water (filled circles). Error bars show SD (or SE for D) among replicates $(n=3)$. An asterisk marks the statistical difference $(t-$ test, $\mathrm{p}<0.05)$ between the solar radiation-exposed water and the dark control water 
at $300 \mathrm{~nm}\left(\mathrm{a}_{\mathrm{CDOM}, 300}\right)$ was $9.5 \mathrm{~m}^{-1}$ at the beginning of exposure and the same in the dark control water at the end of the exposure (Fig. 4B). In the water exposed to solar radiation, the photochemical reactions photobleached $a_{\mathrm{CDOM}, 300}$ to $6.1 \mathrm{~m}^{-1}$ with no significant change in the spectral slope coefficient of $0.0197 \mathrm{~nm}^{-1}$. The filtering removed bacterioplankton, heterotrophic nanoflagellates, and chl a below the detection limits of our methods (Figs. $2 \& 3$ ). During the $12 \mathrm{~d}$ exposure, the biomass of phytoplankton ( $\mathrm{chl} \mathrm{a)}$ and heterotrophic nanoflagellates remained negligible, but bacterial regrowth took place. Despite the exposure to solar UVR, bacterioplankton achieved higher biomass and production in the solar radiation-exposed water than in the dark control (Fig. 3A,D). At end of the exposure, the concentrations of $\mathrm{NH}_{4}{ }^{+}$, the major nitrogenous photoproduct (Tarr et al. 2001, Vähätalo 2009), were similarly below detection both in the irradiated $(0.07 \pm$ $0.04 \mu \mathrm{mol} \mathrm{l}^{-1}$, mean $\pm \mathrm{SD}, \mathrm{n}=2$ ) and the dark control $\left(0.09 \pm 0.03 \mu \mathrm{mol} \mathrm{l}^{-1}, \mathrm{n}=2\right)$ samples. The concentration of PON was larger in the irradiated than in the dark control sample, indicating the incorporation of dissolved N into bacterial biomass. Additionally, POC and POP increased more in the exposed than in the dark control water (Fig. 1A-C). Although some bacteria likely passed through the filters used for the collection of POM, the measurements of POM supported the bacterial microscopy and showed that bacteria benefitted from photoproduced DOM.

\section{Heterotrophs}

After exposure to solar radiation, the exposed and the dark control waters received an inoculum of an indigenous $<10 \mu \mathrm{m}$ plankton community and were cultured under PAR. During the first $6 \mathrm{~d}$ of the bioassay, the bacterial production was higher in the exposed than in the dark control water (Fig. 3D). The biomass of bacterioplankton peaked on Day 4 of the bioassay (Fig. 3A). At that time, the bacterial production was 4.3 times higher in the exposed water than in the dark control. The bacterial production integrated over the $10 \mathrm{~d}$ bioassay was $6.7 \pm 0.76 \mu \mathrm{mol} \mathrm{C} \mathrm{l^{-1 }}$ (mean \pm SD) and $2.3 \pm 0.21 \mu \mathrm{mol} \mathrm{C} \mathrm{^{-1 }}$ in the exposed and the dark control water, respectively. Thus, the bacterial produc-

Fig. 2. (A) Total biomass of autotrophic plankton, (B-E) biomass of the major taxonomic groups, (F) concentration of chlorophyll $a(\mathrm{chl} a)$, and (G) primary production (PP) during the 3 phases of the experiment in the solar radiation-exposed water (open circles) and the dark control water (filled circles). Primary production was not measured during the pre-treatment (G). Error bars show the estimated (A-E) and the measured $(\mathrm{F}-\mathrm{G}, \mathrm{n}=2)$ SD among replicates. Asterisks as in Fig. 1
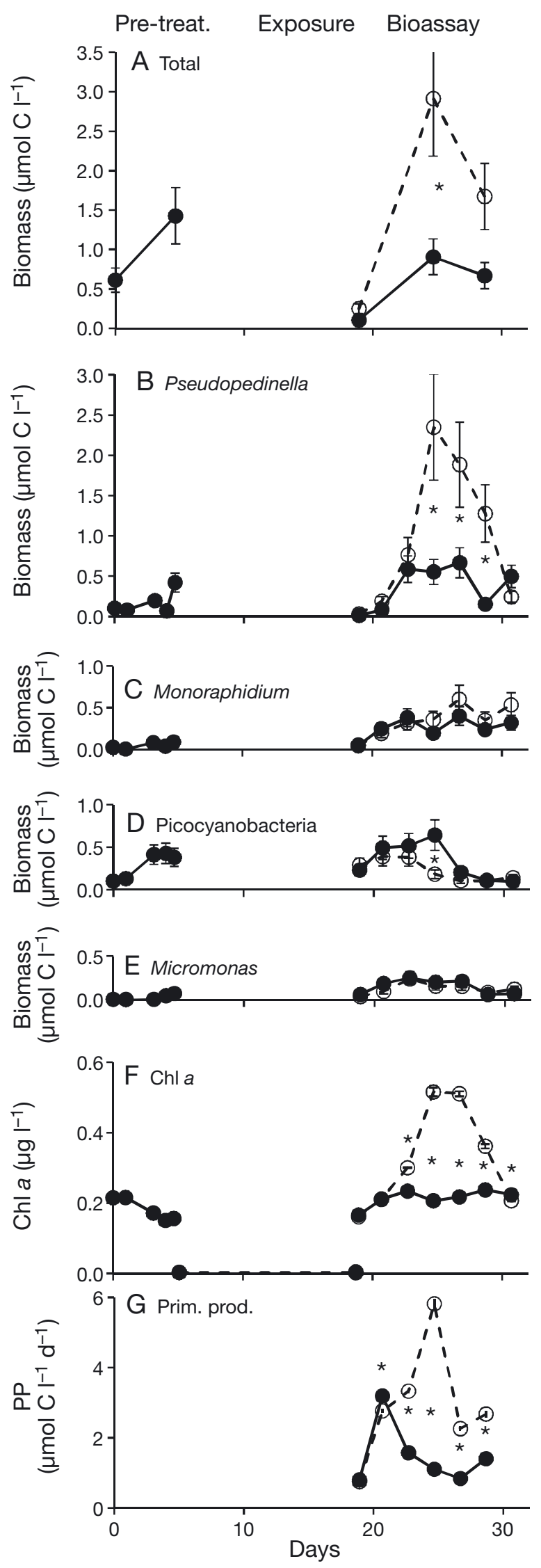

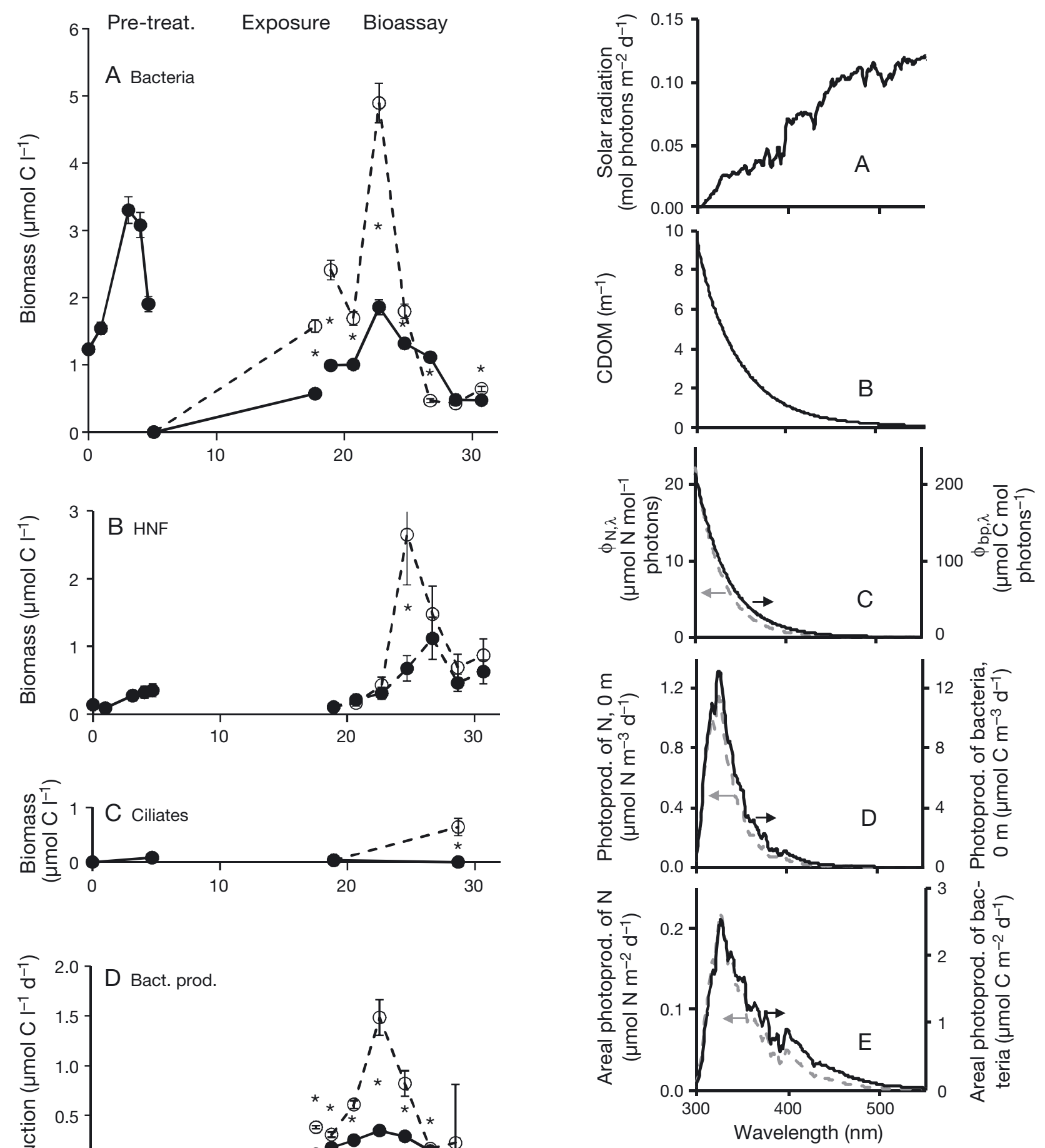

Fig. 4. Photochemical production rates of $\mathrm{N}$ and dissolved organic matter (DOM) supporting bacterial production and the parameters needed for the calculation of rates. (A) Typical daily dose of solar radiation at the surface of the Baltic Sea during summer (Vähätalo \& Zepp 2005). (B) Absorption coefficient of chromophoric DOM (CDOM) at Stn Långskär on 18 May 2005. (C) Apparent quantum yield spectra for the photoproduction of $N\left(\phi_{N, \lambda}\right)$ and DOM supporting bacterial production $\left(\phi_{\mathrm{bp}, \lambda}\right.$, Table 2$)$. (D) Calculated daily rate for the photoproduction of $\mathrm{N}$ and for the bacterial production supported by photoproduced DOM at a depth of $0 \mathrm{~m}$ at Stn Långskär (Eq. 1). (E) As in (D), but over the entire water column (Eq. 2) flagellates (HNF), and (C) ciliates, and (D) bacterial production in the 3 phases of the experiment in the solar radiationexposed water (open circles) and the dark control water (filled circles). Bacterial production was not measured during the pre-treatment (D). Error bars show the estimated (A-C) and the measured ( $D_{;} \mathrm{n}=3$ ) SD among replicates. Asterisks as in Fig. 1 
tion was larger by $4.4 \pm 0.97 \mu \mathrm{mol} \mathrm{C} \mathrm{l}^{-1}$ in the exposed than in the dark control water during the $10 \mathrm{~d}$ bioassay. As the bacterial biomass was larger by $1.1 \pm 0.07 \mu \mathrm{mol}$ $\mathrm{C}^{-1}$ in the exposed than in the dark control water already at the end of sunlight exposure (Fig. 3A), the exposure of DOM to solar radiation supported

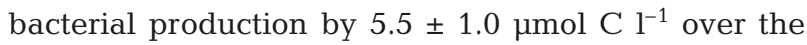
whole experiment (exposure + bioassay). Heterotrophic nanoflagellates, the major grazers of bacterioplankton, peaked on Day 6 of the bioassay in the solar radiationexposed water. Two days after this peak, bacterial biomass was lower in the exposed than in the dark control water. In the dark control water, heterotrophic nanoflagellates peaked later and with lower biomass than in the exposed water. In the exposed water, the biomass of heterotrophic nanoflagellates decreased to the lowest values on Day 10 of the bioassay. At that time in the exposed waters, the biomass of ciliates was 20 times higher than at the beginning of the bioassay. In the dark control water, the densities of ciliates were

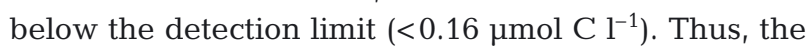
photoproduced DOM stimulated heterotrophic production over 3 trophic levels, indicating that the bacterioplankton grown at the expense of photoproduced DOM was grazed by heterotrophic nanoflagellates, which were eventually grazed by ciliates, the top predators in our experiment.

\section{Autotrophs}

At the beginning of the bioassay, the introduction of plankton inoculum to the exposed and the dark control waters resulted in similar autotrophic communities in both treatments according to primary production, the concentration of chl $a$, the biovolume of total phytoplankton, and the major taxonomic groups (Fig. 2). Phytoplankton achieved larger biomasses in the exposed than in the dark control water with a maximum on Days 6 to 8 of the bioassay (Fig. 2). Primary production was initially similar in both treatments, but after $4 \mathrm{~d}$, it was higher in the exposed than in the dark control water (Fig. 2G). In the exposed water, the increase in phytoplankton biomass was mostly attributed to Pseudopedinella and Monoraphidium. The biomass of picocyanobacteria decreased (Fig. 2D). The decline in picocyanobacteria biomass started simultaneously with the decline in heterotrophic bacterioplankton during the peak of heterotrophic nanoflagellates in the exposed water. The decline in Pseudopedinella took place at the same time as the decline in heterotrophic nanoflagellates, indicating grazing by ciliates. Monoraphidium behaved differently. The biomass of Monoraphidium in the exposed water exceeded that in the dark control water during the high- est abundance of flagellates and remained elevated thereafter (paired $t$-test, $t=7.52$, df $=3, \mathrm{p}=0.0049$ ). Overall, these results show that the exposure of biologically recalcitrant DOM to solar radiation did not only stimulate heterotrophs but also autotrophic algae, with responses differing among taxa.

POM

During the bioassay, the concentrations of POC, PON, and POP were consistently higher in the exposed water than in the dark control (Fig. $1 \mathrm{~A}-\mathrm{C}_{\text {; }}$ paired $t$-test, $t>4.76$, df $=6, \mathrm{p}<0.0031)$. The dynamics of POC, POP, and PON differed. The concentration of POP did not show a trend and was on average 0.014 (range $0.007-$ 0.300) $\mu \mathrm{mol} \mathrm{P}^{-1}$ larger in the exposed than in the dark control water. The concentration of PON was also relatively stable or increased only slightly, being on average 0.44 (range 0.35-0.60) $\mu \mathrm{mol} \mathrm{N}^{-1}$ higher in the exposed than in the dark control water. The concentration of POC increased during the bioassay but eventually decreased at the end. The dynamics of POC agreed with the dynamics of the plankton community: the accumulation of bacterial POC at the expense of photoproduced DOM, the following trophic transfer, the stimulated primary production and the respiratory losses of POC at the end of bioassay. During the first $8 \mathrm{~d}$, the C:N ratio of POM was lower in the exposed than in the dark control water (paired $t$-test, $t=3.22$, $\mathrm{df}=4, \mathrm{p}=0.032$ ), indicating that bacterioplankton preferentially incorporated photoproduced $\mathrm{N}$ than $\mathrm{C}$ into their biomass. In the exposed water, the $\mathrm{C}: \mathrm{N}$ ratio increased and finally reached values similar to those in the dark control water. These results show that photoproduced DOM altered the C:N stoichiometry of plankton initially, but later biological processes, such as grazing, modified the initially low $\mathrm{C}: \mathrm{N}$ ratios.

\section{$\delta^{13} \mathrm{C}$ of particulate matter}

In the original water sampled at the end of the spring bloom, the $\delta^{13} \mathrm{C}$ of total POC was $-19.4 \%$, while that of the $10 \mu \mathrm{m}$ fraction was $4 \%$ units lighter (Table 1, Fig. 1E). During the pre-treatment, the $\delta^{13} \mathrm{C}$ of POC $(<10 \mu \mathrm{m})$ became heavier by $1.5 \%$. During the bioassay, the $\delta^{13} \mathrm{C}$ of POC was not consistently different between the treatments and ranged from $-26 \%$ to $-30 \%$ with a mean of $-28 \%$ o (paired $t$-test, $t=0.56$, df $=$ $6, \mathrm{p}=0.60)$. The POC accumulated during the bioassay had a $\delta^{13} \mathrm{C}$ similar to the $\delta^{13} \mathrm{C}$ of terrestrial carbon draining to the Baltic Sea (-28\%, Voß \& Struck 1997) but lower than the $\delta^{13} \mathrm{C}$ of autochthonous POC at the end of the spring bloom $(-19.4 \%)$. This result indicates 
that during the bioassay, the biomass of plankton was primarily based on the utilization of allochthonous DOM imported from the catchment of the Baltic Sea.

\section{Apparent quantum yields}

To convert the observed responses of plankton to photoproudced DOM into rates in the water column of the Baltic Sea, we related the cumulative production of bacterial biomass at the expense of photoproduced

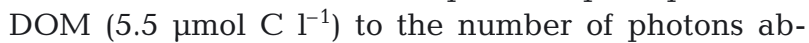
sorbed during the exposure. This apparent quantum yield for stimulated bacterial production $\left(\phi_{\mathrm{bp}, \lambda}\right)$ describes how much bacterial biomass (mol C) was gained per unit of solar radiation absorbed by CDOM (mol photons). At $350 \mathrm{~nm}, \phi_{\mathrm{bp}}$ was 0.000051 , meaning that 1 mole of photons absorbed by CDOM at $350 \mathrm{~nm}$ generated $51 \mu \mathrm{mol}$ bacterial $\mathrm{C}$ in our experiment (Table 2). The $c$ and $d$ parameters of the apparent quantum yield spectrum allow the calculation of $\phi_{\mathrm{bp}, \lambda}$ throughout the spectrum as illustrated in Fig. $4 \mathrm{C}$. At a depth of $0 \mathrm{~m}$, the rate of bacterial production based on the photoproduced DOM (Fig. 4D, Eq. 1) was calculated according to the dose of daily summer solar radiation (Fig. 4A), the absorption by CDOM (Fig. 4B), and $\phi_{\mathrm{bp}, \lambda}$ (Fig. 4C). At $0 \mathrm{~m}$, the UV-A part of the spectrum was mostly responsible for the photochemistry, and the median wavelength for the photoproduced DOM supporting bacterial production $\left(\phi_{\mathrm{bp}, 50 \%}\right)$ was $331 \mathrm{~nm}$ (Fig. 4D). The integration over wavelengths reveals that the daily dose of solar radiation stimu-

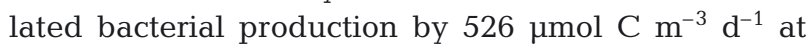
$0 \mathrm{~m}$ (Table 2, Fig. 4D). Over the entire water column, photoproduced DOM supported bacterial production by $164 \mu \mathrm{mol} \mathrm{C} \mathrm{m}{ }^{-2} \mathrm{~d}^{-1}$ (Fig. 4E) when calculated as the product of solar radiation (Fig. 4A) and $\phi_{\mathrm{bp}, \lambda}$ (Fig. 4C), assuming that CDOM absorbed all pho-

Table 2. Apparent quantum yields $(\phi)$ and the rates for the photoproduction of $\mathrm{N}$, bacterial production (BP), and bacterial respiration (BR) based on photoproduced dissolved organic matter (DOM). $\phi$ is reported at $350 \mathrm{~nm}$ $\left(\phi_{350}\right)$, but the parameters $c$ and $d$ allow the calculation of $\phi$ at the other wavelengths $\lambda(\mathrm{nm})$ according to Eq. (3). The summertime rates for the conditions representing Stn Långskär were calculated for a depth of $0 \mathrm{~m}$ and over the entire water column $(0-\infty)$ according to the Eqs. (1) and (2), respectively

\begin{tabular}{|lccccc|}
\hline$\phi$ for & $c$ & $\begin{array}{c}d \\
\left(\mathrm{~nm}^{-1}\right)\end{array}$ & $\begin{array}{c}\phi_{350} \\
\left(\times 10^{-6}\right)\end{array}$ & $\begin{array}{c}0 \mathrm{~m} \\
\left(\mu \mathrm{mol} \mathrm{m}{ }^{-3} \mathrm{~d}^{-1}\right)\end{array}$ & $\begin{array}{c}0-\infty \mathrm{m} \\
\left(\mu \mathrm{mol} \mathrm{m} \mathrm{d}^{-1}\right)\end{array}$ \\
\hline BP, Långskär $^{1.10}$ & 0.0285 & 51.2 & 526 & 164 \\
BR, Sapelo $^{\mathrm{a}}$ & 20.3 & 0.0298 & 599 & 6243 & 1881 \\
BR, Altahama $^{\mathrm{a}}$ & 11.4 & 0.0273 & 806 & 8169 & 2637 \\
N, Långskär & 0.84 & 0.0351 & 3.8 & 43 & 12 \\
N, Långskär $^{\mathrm{b}}$ & 0.90 & 0.035 & 7.4 & 59 & 26 \\
a Miller et al. (2002) $^{\mathrm{b}}{ }^{\mathrm{b}}$ Vähätalo \& Järvinen (2007) \\
\hline
\end{tabular}

tolytic solar radiation (i.e. $a_{\mathrm{CDOM}, \lambda} / a_{\mathrm{tot}, \lambda}=1$, Eq. 2). Over the entire water column, the solar radiation at the violet-blue part of spectrum also contributed to photoproduced DOM, and $\phi_{\mathrm{bp}, 50 \%}$ was $352 \mathrm{~nm}$ (Fig. 4E).

The apparent quantum yield spectrum for the photochemical production of bioavailable $\mathrm{N}\left(\phi_{\mathrm{N}, \lambda}\right)$ was calculated by relating the measured solar radiation-stimulated increase in PON during the bioassay $(0.44 \mu \mathrm{mol}$ $\mathrm{N}^{-1}$ ) to the number of photons absorbed during the exposure. At $350 \mathrm{~nm}, \phi_{\mathrm{N}}$ was $3.8 \mu \mathrm{mol} \mathrm{N} \mathrm{mol}{ }^{-1}$ photons and an order of magnitude lower than $\phi_{\mathrm{bp}, 350}$ (Table 2). The spectral slope of $\phi_{\lambda}$ was steeper for $\phi_{\mathrm{N}, \lambda}(d=$ $\left.0.0351 \mathrm{~nm}^{-1}\right)$ than for $\phi_{\mathrm{bp}, \lambda}\left(d=0.0285 \mathrm{~nm}^{-1}\right.$; Table 2, Fig. 4B). The photoproduction of $\mathrm{N}$ took place at shorter wavelengths than the photoproduction of DOM (Fig. $4 \mathrm{D}, \mathrm{E}$ ). $\phi_{\mathrm{N}, 50 \%}$ was $328 \mathrm{~nm}$ at a depth of $0 \mathrm{~m}$ and $342 \mathrm{~nm}$ over the entire water column. The calculated photoproduction of $\mathrm{N}$ was $12 \mu \mathrm{mol} \mathrm{N} \mathrm{m} \mathrm{N}^{-2} \mathrm{~d}^{-1}$ over the entire water column and $43 \mu \mathrm{mol} \mathrm{N} \mathrm{m}{ }^{-3} \mathrm{~d}^{-1}$ at $0 \mathrm{~m}$.

\section{DISCUSSION}

\section{Trophic transfer of photoproduced labile DOC through the heterotrophic food web}

This study shows for the first time a time series of trophic dynamics based on photoproduced DOM generated by natural solar radiation. Our study indicates that the bacterial carbon gained at the expense of photoproduced DOM is transferred to higher trophic levels, first to bacteriovorous flagellates and further to ciliates grazing the flagellates. Our study emphasizes the importance emporal dynamics when whole communities are exed, because analyses based on one time point may tially give misleading results, such as the reduced bacterial biomass with photoproduced DOM found on Day 8 of our bioassay. Our study shows that the trophic transfer of photoproduced DOM is not limited to humic waters as found in previous studies (De Lange et al. 2003, Daniel et al. 2006), but also takes place in coastal waters. Our study, together with earlier studies, indicates that the trophic transfer of photoproduced DOM is a general phenomenon both in fresh and coastal waters and thus contributes to the overall productivity of heterotrophic food webs.

\section{Photochemistry of DOM and autotrophs}

This study shows that the photochemical transformation of DOM can stimulate the biomass and the production of phyto- 
plankton, in agreement with an earlier study (Vähätalo \& Järvinen 2007). The earlier study demonstrated an elevated concentration of chl $a$ and phytoplankton biomass (at 1 time point) with phototransformed DOM. The present study takes a deeper look at the temporal responses of individual phytoplankton taxa and also demonstrates the enhancement of phytoplankton by primary production measurements. In both studies, the plankton communities were N-limited, and the photochemical production of bioavailable $\mathrm{N}$ likely stimulated phytoplankton, although we cannot exclude the possibility that photoproduced labile DOC stimulated the utilization of DON. The photoproduction of $\mathrm{N}$ takes place primarily as $\mathrm{NH}_{4}{ }^{+}$but in smaller amounts also as amino acids (Tarr et al. 2001, Vähätalo 2009).

During the solar radiation exposure phase of our experiment, photoproduced dissolved $\mathrm{N}$ was converted into bacterial biomass most likely by the smallest bacteria passing through $0.2 \mu \mathrm{m}$ filters (Hahn 2003). During this phase of the experiment, bacterial grazers and viral lysis (i.e. the presence of empty bacterial cells during microscopy) were not detected, and therefore bacterioplankton retained the incorporated $\mathrm{N}$ in their biomass. The $\mathrm{N}$ bound in bacterial biomass acted as a source of $\mathrm{N}$ for grazers, which were introduced during the bioassay phase of the experiment. In our study, photosynthesis, the concentration of chl $a$, the biomass of Pseudopedinella, and the decline in bacterial biomass peaked simultaneously. This temporal synchrony indicates that the most successful alga, Pseudopedinella, was photosynthetically active and obtained $\mathrm{N}$ through grazing on bacteria. Similar to our study, mixotrophic phytoplankton (Pseudopedinella and Uroglena) benefitted from the irradiation of bog water (De Lange et al. 2003). Pseudopedinella grows autotrophically under nutrient-replete conditions but grazes on bacteria under nutrient limitations as in our study (Nygaard \& Tobiesen 1993). As mixotrophy is a common strategy for algae to obtain nutrients under oligotrophic conditions from freshwaters to the open ocean (Zubkov \& Tarran 2008), this and earlier studies indicate that photoproduced $\mathrm{N}$ can be mediated to phytoplankton through mixotrophy.

The photoproduced $\mathrm{N}$ incorporated into bacterial biomass can also stimulate phytoplankton via other mechanisms. In our study, Monoraphidium grew more in the solar radiation-exposed than in the dark control water. Monoraphidium is a strict autotroph, has elongated morphology with spiny ends (length $>30 \mu \mathrm{m}$, diameter $<2.5 \mu \mathrm{m})$, and is inedible at least for the flagellates (diameter $<7 \mu \mathrm{m}$ ) and obviously also for the $<10 \mu \mathrm{m}$ ciliates, the top grazers of our experiment. In our exposed water, Monoraphidium gained biomass during intensive grazing and likely took up dissolved $\mathrm{N}$ released by grazing (Goldman et al. 1985, Thingstad
\& Lignell 1997). Assuming that a surface area to volume ratio $\left(A: V, \mu m^{2}: \mu m^{3}\right)$ determined for our plankton indicates the efficiency of nutrient uptake (Sunda \& Hardison 2010), Monoraphidium (A:V of 2.3) takes up nutrients more efficiently than Pseudopedinella (A:V of 1.3) but less efficiently than bacterioplankton (A:V of 11). When the biomass of Monoraphidium was elevated in our experiment, the concentration of photoproduced DOM was already small and the uptake of dissolved $\mathrm{N}$ by bacterioplankton was, therefore, also small. This, along with the intensive grazing on bacteria by flagellates, allowed the acquisition of dissolved $\mathrm{N}$ by Monoraphidium.

Although the nutrient uptake capacity of picocyanobacteria (A:V of 6.7) likely exceeds that of Monoraphidium, the biomass of picocyanobacteria declined in our exposed water. The strongest decline in picocyanobacteria occurred simultaneously with the decline in (heterotrophic) bacterioplankton and the highest abundance of flagellates, indicating that the grazing by flagellates controlled the biomass of the smallest plankton including picocyanobacteria. Our study indicates that the responses of phytoplankton taxa to photoproduced DOM vary. The fate of photoproduced $\mathrm{N}$ depends on e.g. grazing, grazingresistance, the uptake kinetics of nutrients, and the mixotrophy of phytoplankton taxa.

\section{Phototransformation of terrestrial DOM in coastal waters}

In our original water sample collected from the entrance to the Gulf of Finland, the $\delta^{13} \mathrm{C}$ of total POC is similar to values reported earlier for POC in the Gulf of Finland (Kuuppo et al. 2006). The POC in our original sample represented plankton at the end of the spring bloom, and therefore its $\delta^{13} \mathrm{C}$ is obviously also similar to the autochthonously produced organic carbon in the Baltic Sea $(-20 \%$; Voß \& Struck 1997). In the pretreatment with $10 \mu \mathrm{m}$ filtered water, the increase in the $\delta^{13} \mathrm{C}$ of POC from -24 towards $-20 \%$ is possibly explained by the bacterial consumption of autochthonous DOC produced by the spring bloom (i.e. microbial loop) and/or new photosynthesis (Søndergaard et al. 2000).

The organic carbon accumulated during the bioassay in this study had $\delta^{13} \mathrm{C}$ similar to the terrestrial end member (-28\%, Voß \& Struck 1997, Alling et al. 2008). When the biomasses of heterotrophs and autotrophs presented in Figs. $2 \& 3$ are summed up, the heterotrophs accounted for 60 to $62 \%$ of the total biomass during the bioassay. Including mixotrophic Pseudopedinella among the heterotrophs, the heterotrophs contributed 84 and $72 \%$ to the total biomass during the 
bioassay in the exposed and dark control waters, respectively. The similarity of our plankton $\delta^{13} \mathrm{C}$ to that of the terrestrial end member indicates that allochthonous DOC largely supported our plankton communities (Alling et al. 2008). In the dark treatment, the bacterioplankton obviously consumed the semilabile terrestrial DOM directly (Vähätalo et al. 2010). In the exposed water, photoreactions increased the consumption of allochthonous DOC further. In the northern Baltic Sea, terrestrial DOC is the largest component of DOC and is susceptible to phototransformation (Alling et al. 2008, Lignell et al. 2008, Hoikkala et al. 2009). Therefore, the $\delta^{13} \mathrm{C}$ of POC in the exposed water of this study indicates that the plankton community in the exposed water grew mostly at the expense of phototransformed terrestrial DOC.

\section{Apparent quantum yields for the photoreactions of DOM}

Our $\phi_{\mathrm{bp}, \lambda}$ allows for direct calculation of bacterial production based on photoproduced DOM in surface waters. According to our $\phi_{\mathrm{bp}, \lambda}$, photoproduced DOM supports bacterial production by $164 \mu \mathrm{mol} \mathrm{C} \mathrm{m} \mathrm{C}^{-2} \mathrm{~d}^{-1}$ during a summer day in the coastal Baltic Sea. This bacterial production corresponds to 1.8 to $4.5 \%$ of daily mean annual bacterial productivity in the northern Baltic Sea (Sandberg et al. 2004). Earlier studies estimated that the proportion of photoproduced DOM from the total carbon demand of bacterioplankton is 10 to $11 \%$ in the epilimnion of humic lakes and 4 to $6 \%$ in coastal waters (Moran \& Zepp 1997, Vähätalo et al. 2003, Lignell et al. 2008). These studies indicate that the degree of heterotrophy and the supply of terrestrial DOM are lower in coastal waters than in fresh waters, and may explain the lower contribution of photoproduced DOC to the total bacterial production in coastal waters. Nevertheless, this and other studies mentioned above indicate that the photochemical transformation of DOM enhances the utilization of allochthonous DOM and the production of bacterioplankton, which will be coupled to the food webs of fresh and coastal waters through grazing.

The apparent quantum yield for the photoproduction of bioavailable $N\left(\phi_{N, \lambda}\right)$ in this study describes the magnitude of photoproduced $\mathrm{N}$ incorporated into plankton and is similar to earlier determinations in the Baltic Sea (Vähätalo \& Järvinen 2007, Table 2). Further, the apparent quantum yield for the photoproduction of bioavailable $\mathrm{N}$ is similar to that for the photoproduction of ammonium in the Baltic Sea (Vähätalo \& Zepp 2005, Stedmon et al. 2007). Therefore, the photochemical production of ammonium can explain the amount of $\mathrm{N}$ accumulated in the plankton community of this study, although an elevated concentration of $\mathrm{NH}_{4}{ }^{+}$was not directly observed due to a rapid biological uptake of $\mathrm{NH}_{4}{ }^{+}$. Our earlier studies discuss the spectral dependence, the photolytic depths of photoammonification, as well as the photolytic turnover times of DON, and relate the rates of photoammonification to the other sources of N (Vähätalo \& Zepp 2005, Vähätalo \& Järvinen 2007). As $\phi_{\mathrm{N}, \lambda}$ in this study was similar to our earlier determinations, this study supports the earlier estimate that photoproduced $\mathrm{N}$ can potentially support up to $3.6 \%$ of the $\mathrm{N}$ demand of new primary production in our study region during summer (Vähätalo \& Järvinen 2007).

Our experiment indicates that bacterioplankton preferentially take up photoproduced $\mathrm{N}$ than photoproduced DOC under N-limited conditions. This is understandable when the C:N of photoproduced DOM is examined. In our study region, photoreactions can be calculated to produce $2423 \mu \mathrm{mol}$ labile DOC m ${ }^{-2} \mathrm{~d}^{-1}$ and $19 \mu \mathrm{mol}$ bioavailable $\mathrm{N} \mathrm{m}^{-2} \mathrm{~d}^{-1}$ according to the rates of phototransformed $\mathrm{N}$, bacterial respiration and production based on the photoproduced DOC reported in Table 2. In this case, the C:N ratio of photoproduced DOM is 128 and much higher than that in the plankton of our study (e.g. Fig. 1D) or what is typically reported for bacterio- (5) or phytoplankton (6.6). Under such conditions, plankton prefer photoproduced $\mathrm{N}$ over photoproduced DOC, which is largely respired through bacterioplankton. Respiratory losses during bacterial metabolism and a trophic cascade transfer photoproduced DOC inefficiently to the highest trophic levels such as Baltic Sea fish, which have $\delta^{13} \mathrm{C}$ matching that of autochthonous production in the Baltic Sea (Kiljunen et al. 2008).

Our study indicates that photoproduced $\mathrm{N}$ is retained within a plankton community under N-limiting conditions, unlike photoproduced DOC with high respiratory losses. According to our observations, photoproduced dissolved $\mathrm{N}$ is taken up primarily by bacterioplankton, which serves as a source of $\mathrm{N}$ for its grazers with little apparent mineralization of organic $\mathrm{N}$ and/or efficient recycling of re-mineralized $\mathrm{N}$ within a plankton community. Under N-limiting conditions, photoproduced $\mathrm{N}$ may reach the highest trophic levels of pelagic food webs to a much larger extent than photoproduced DOC.

Acknowledgements. H. Kuosa, A. Nevalainen, E. Salminen, M. Sjöholm, and the other staff from Tvärminne Zoological Station provided assistance with microscopy, analytical work, and practical arrangements. The laboratory of the Finnish Marine Research Institute helped with the nutrient analyses. The comments of reviewers improved the manuscript. The Academy of Finland and the Nottbeck foundation funded this study. 


\section{LITERATURE CITED}

Alling V, Humborg C, Mörth CM, Rahm L, Pollehne F (2008) Tracing terrestrial organic matter by $\delta^{34} \mathrm{~S}$ and $\delta^{13} \mathrm{C}$ signatures in a subarctic estuary. Limnol Oceanogr 56:2594-2602

Bergström AK, Jansson M (2006) Atmospheric nitrogen deposition has caused nitrogen enrichment and eutrophication of lakes in the northern hemisphere. Glob Change Biol 12: 635-643

Børsheim K, Bratbak G (1987) Cell volume to cell carbon conversion factors for a bacterivorous Monas sp. enriched from seawater. Mar Ecol Prog Ser 36:171-175

Bushaw KL, Zepp RG, Tarr MA, Schulz-Jander D and others (1996) Photochemical release of biologically available nitrogen from aquatic dissolved organic matter. Nature 381:404-407

Daniel C, Granéli W, Kritzberg ES, Anesio AM (2006) Stimulation of metazooplankton by photochemically modified dissolved organic matter. Limnol Oceanogr 51:101-108

De Lange HJ, Morris DP, Williamson CE (2003) Solar ultraviolet photodegradation of DOC may stimulate freshwater food webs. J Plankton Res 25:111-117

> Goldman JC, Caron DA, Andersen OK, Dennett MR (1985) Nutrient cycling in a microflagellate food chain: I. Nitrogen dynamics. Mar Ecol Prog Ser 24:231-242

Hahn MW (2003) Isolation of strains belonging to the cosmopolitan Polynucleobacter necessarius cluster from freshwater habitats located in three climatic zones. Appl Environ Microbiol 69:5248-5254

Hansell DA, Carlson CA (eds) (2002) Biogeochemistry of marine dissolved organic matter. Academic Press, London

Hansen HP, Koroleff F (1999) Simultaneous oxidation of nitrogen and phosphorus compounds with persulphate. In: Grasshoff K, Kremling K, Ehrhardt M (eds) Methods of seawater analysis. Wiley-VCH, Weinheim, p 205-206

> Hoikkala L, Aarnos H, Lignell R (2009) Changes in nutrient and carbon availability and temperature as factors controlling bacterial growth in the northern Baltic Sea. Estuaries Coasts 32:720-733

Kieber RJ, Hydro LH, Seaton PJ (1997) Photooxidation of triglycerides and fatty acids in seawater: implication toward the formation of marine humic substances. Limnol Oceanogr 42:1454-1462

Kiljunen M, Peltonen H, Jones RI, Kiviranta H, Vuorinen PJ, Verta M, Karjalainen J (2008) Coupling stable isotopes with bioenergetics to evaluate sources of variation in organochlorine concentrations in Baltic salmon (Salmo salar). Can J Fish Aquat Sci 65:2114-2126

Kuuppo P (1994) Annual variation in the abundance and size of heterotrophic nanoflagellates on the SW coast of Finland, the Baltic Sea. J Plankton Res 16:1525-1542

Kuuppo P, Tamminen T, Voss M, Schulte U (2006) Nitrogenous discharges to the eastern Gulf of Finland, the Baltic Sea: elemental flows, stable isotope signatures, and their estuarine modification. J Mar Syst 63:191-208

Lignell R, Seppälä J, Kuuppo P, Tamminen T, Andersen T, Gismervik I (2003) Beyond bulk properties: responses of coastal summer plankton communities to nutrient enrichment in the northern Baltic Sea. Limnol Oceanogr 48: 189-209

Lignell R, Hoikkala L, Lahtinen T (2008) Effects of inorganic nutrients, glucose and solar radiation on bacterial growth and exploitation of dissolved organic carbon and nitrogen in the northern Baltic Sea. Aquat Microb Ecol 51:209-221

Massana RJ, Gasol JM, Bjørnsen PK, Blackburn N and others (1997) Measurement of bacterial size via image analysis of epifluorescence preparations: description of an inexpen- sive system and solutions to some of the most common problems. Sci Mar 61:397-407

Miller WL, Moran MA, Sheldon WM, Zepp RG, Opsahl S (2002) Determination of apparent quantum yield spectra for the formation of biologically labile photoproducts. Limnol Oceanogr 47:343-352

Mopper K, Kieber DJ (2002) Photochemistry and the cycling of carbon, sulphur, nitrogen and phosphorus. In: Hansell DA, Carlson CA (eds) Biogeochemistry of marine dissolved organic matter. Academic Press, London, p 456-507

Moran MA, Zepp RG (1997) Role of photoreactions in the formation of biologically labile compounds from dissolved organic matter. Limnol Oceanogr 42:1307-1316

> Nygaard K, Tobiesen A (1993) Bacteriovory in algae: a survival strategy during nutrient limitation. Limnol Oceanogr $38: 273-279$

Olenina I, Hadju S, Edler L, Andersson A and others (2006) Biovolumes and size-classes of phytoplankton in the Baltic Sea. HELCOM Balt Sea Environ Proc No 106

$>$ Rabalais NN (2002) Nitrogen in aquatic ecosystems. Ambio 31:102-112

> Sandberg J, Andersson A, Johansson S, Wikner J (2004) Pelagic food web structure and carbon budget in the northern Baltic Sea: potential importance of terrigenous carbon. Mar Ecol Prog Ser 268:13-29

Solorzano L (1969) Determination of ammonia in natural waters by the phenolhypochlorite method. Limnol Oceanogr 14:799-801

> Søndergaard M, Williams PJB, Cauwet G, Riemann B and others (2000) Net accumulation and flux of dissolved organic carbon and dissolved organic nitrogen in marine plankton communities. Limnol Oceanogr 45:1097-1111

Spilling K (2007) On the ecology of cold-water phytoplankton in the Baltic Sea. W \& A de Nottbeck Foundation Sci Rep 31. $\mathrm{PhD}$ dissertation, University of Helsinki

Stedmon CA, Markager S, Tranvik L, Kronberg L, Slatis T, Martinsen W (2007) Photochemical production of ammonium and transformation of dissolved organic matter in the Baltic Sea. Mar Chem 104:227-240

Sunda WG, Hardison DR (2010) Evolutionary tradeoffs among nutrient acquisition, cell size, and grazing defense in marine phytoplankton promote ecosystem stability. Mar Ecol Prog Ser 401:63-76

Tarr MA, Wang W, Bianchi TS, Engelhaupt E (2001) Mechanisms of ammonia and amino acid photoproduction from aquatic humic and colloidal matter. Water Res 35: 3688-3696

> Thingstad TF, Lignell R (1997) Theoretical models for the control of bacterial growth rate, abundance, diversity and carbon demand. Aquat Microb Ecol 13:19-27

Vähätalo AV (2009) Light, photolytic productivity and chemical products. In: Likens G (ed) Encyclopedia of inland waters, Vol 2. Elsevier, Oxford, p 761-773

Vähätalo AV, Järvinen M (2007) Photochemically produced bioavailable nitrogen from biologically recalcitrant dissolved organic matter stimulates the production of a nitrogen-limited microbial food web in the Baltic Sea. Limnol Oceanogr 52:132-143

> Vähätalo AV, Zepp RG (2005) Photochemical mineralization of dissolved organic nitrogen to ammonium in the Baltic Sea. Environ Sci Technol 39:6985-6992

Vähätalo AV, Salkinoja-Salonen M, Taalas P, Salonen K (2000) Spectrum of the quantum yield for photochemical mineralization of dissolved organic carbon in a humic lake. Limnol Oceanogr 45:664-676

> Vähätalo AV, Salonen K, Münster U, Järvinen M, Wetzel RG (2003) Photochemical transformation of allochthonous 
organic matter provides bioavailable nutrients in a humic lake. Arch Hydrobiol 156:287-314

Vähätalo AV, Aarnos H, Mäntyniemi S (2010) Biodegradability continuum and biodegradation kinetics of natural organic matter described by the beta distribution. Biogeochemistry 100:227-240

Voß M, Struck U (1997) Stable nitrogen and carbon isotopes as indicator of eutrophication of the Oder River (Baltic

Editorial responsibility: Ronald Kiene,

Mobile, Alabama, USA
Sea). Mar Chem 59:35-49

- Wetzel RG, Hatcher PG, Bianchi TS (1995) Natural photolysis by ultraviolet irradiance of recalcitrant dissolved organic matter to simple substrates for rapid bacterial metabolism. Limnol Oceanogr 40:1369-1380

Zubkov MV, Tarran GA (2008) High bacteriovory by the smallest phytoplankton in the North Atlantic Ocean. Nature 455:224-227

Submitted: August 26, 2010; Accepted: December 21, 2010 Proofs received from author(s): February 4, 2011 